\title{
FORMS OF SOCIAL REACTION AGAINST CRIMINALITY
}

\section{A. ZAHARIA}

\author{
Alina ZAHARIA \\ Legal advisor / Graduate "Alexandru Ioan Cuza" University of Iași, Faculty of Philosophy \\ and Social-Political Sciences, Master Program Probation, Mediation and Social Assistance \\ for Crime Victims \\ Mailing address: City of Iași, Vasile Lupu street, no. 140, staircase A, $2^{\text {nd }}$ section, $6^{\text {th }}$ floor, \\ $12^{\text {th }}$ apartment, Iasi county, Romania \\ E-mail: alinna.zaharia@gmail.com
}

\section{ABSTRACT:}

In the first part we define some forms of social reaction against crime conceived as a mechanism of social and normative organization, perpetuating itself differently from one society to another, depending on the specifics of each one, referring to the system of ethical, normative and cultural values. Next, we identify aspects related to fight against criminality, which consider the way of establishing some forms of social control, from a social/ legislative/ institutional/ state/ contextual norms perspective, that are found in the public or private space.

KEY WORDS: social reaction, social control, criminality, prevention, punishment.

\section{INTRODUCTION}

The social reaction against criminality represents the legal disapproval and social protest materialized in preventive measures from the perspective of some forms of social control or measures to remove causes and conditions that generate or favor the adoption of criminal behavior, the treatment applied to criminals either minors, adults, women or repeat offenders. On the other hand, it is materialized in punitive measures that apply to the perpetrators who have committed an act that summarizes the conditions for committing a crime ${ }^{1}$.

Given that the members of a society differ one another, disturbances of the equilibrium state can be created precisely through the contrast of each one's diversified concepts. That is why the forms of social reaction, together with the social control come to establish some norms (imperative or supplementary) and habits that balance the social stratification and the dissonance of ideas ${ }^{2}$.

It is easy to understand that the social reaction against crime is also a topic of criminology, forming a branch that studies social psychology, with the particularities related to the legal-criminal field, referring to the causal and non-causal doctrinal theories. In light of this idea, we make a compact characterization to a form of preventive reaction, a

\footnotetext{
${ }^{1}$ Article 15 paragraph (1) of the Penal Code of Romania published in the Official Monitor no. 510/24.07.2009.

${ }^{2}$ C. Loghin, Conflicte - metode alternative de administrare și soluționare, Ed. Univ. Alexandru Ioan Cuza, Iasi, 2016, p. 43.
} 


\section{Alina Zaharia}

form of repressive reaction and a form of social control, criminological landmarks that would reduce criminality.

\section{MODERN PREVENTIVE MODELS - PROHIBITION-TRENDS}

Probation $^{3}$ in Romania appeared as an element of novelty in the field of criminal law in 1996 by implementing a pilot project within the Arad penitentiary with the creation of an experimental center ${ }^{4}$.

Regarding the need for a project ${ }^{5}$ that deals with the principles of probation ${ }^{6}$, we affirm that the reduced number of non-custodial measures and penalties in the criminal field, the absence of specialized bodies to supervise the execution of non-custodial measures and sanctions needed to assist individuals in conflict with the criminal law, for their social reintegration ${ }^{7}$, the need to find new solutions for reducing or diminishing the phenomenon of crime ${ }^{8}$ and for reducing the costs related to deprivation of liberty ${ }^{9}$ are defining aspects of the probation system in Romania.

The extension of the alternative range of measures to custodial sentences, the easing of access conditions to parole, a good functioning of the probation service and the continuation of the penitentiary capacity modernization projects were among the recommendations addressed to the Romanian authorities.

A memorandum, adopted on January 19, 2016, focuses on improving the applicability of the probation system principles ${ }^{10}$ (in particular by increasing the number of probation counselors) ${ }^{11}$, improving detention conditions and developing alternative measures. Thus, for the period 2016-2023, an investment plan with a total value of 838.45 million euros is foreseen to be distributed between the National Administration of Penitentiaries, the National Probation Directorate and the Ministry of Internal Affairs. According to the Government, by the end of 2023, 10.895 new accommodation places will be created, 1.651 places will be upgraded and 5.847 people will be recruited by the National Administration of Penitentiaries ${ }^{12}$, also by 2018, 626 probation counselors and 171 administrative assistants will be recruited to the National Probation Directorate ${ }^{13}$.

The National Probation Directorate has continued the steps and consultations with the Ministry of Justice management for the adoption of a draft law on the status of

\footnotetext{
3 Available at www.eur-lex.europa.eu/legal-content/RO/TXT/HTML/?uri=CELEX:32008F0947\&from=EN, Framework Decision 2008/947 / JHA of the Council of 27 November 2008, accessed on 22.11.2019.

${ }^{4}$ M. Sandu, Reacția socială împotriva criminalității, Ed. Pro Universitaria, 2017, p. 78.

${ }^{5}$ Available at www.euprobationproject.eu/, accessed on 22.11.2019.

${ }^{6}$ Law no. $252 / 2013$ on the organization and functioning of the probation system, published in the Official Monitor no. 512/14.08.2013.

7 Available at ec.europa.eu/info/law/cross-border-cases/judicial-cooperation/types-judicial-cooperation /detention-and-transfer-prisoners_en, accessed on 22.11.2019.

${ }^{8}$ European Probation Rules, European Rules on Comunity Sanctions and Measures - Recomandation no. R(92) 16 on European rules on Community sanctions and measures, available at rm.coe.int/rec-92-16-on-communitysanctions-and-measures/16808b60b6, accessed on 22.11.2019.

${ }^{9}$ Available at $\underline{w w w}$.just.ro/directia-nationala-de-probatiunel, accessed on 22.11.2019.

10 Available at www.ec.europa.eu/growth/tools-databases/regprof/index.cfm?action=regprof\&id _regprof=16890, accessed on 22.11.2019.

$\overline{11}$ Available at www.just.ro/comunicat-de-presa-referitor-la-protestul-consilierilor-de-probatiunel, accessed on 22.11.2019.

${ }^{12}$ Available at www.cdep.ro/interpel/2016/r3286B.pdf, accessed on 22.11.2019.

13 Available at www.ier.gov.ro/wp-content/uploads/cedo/Rezmives-si-altii-impotriva-Romaniei.pdf, Rezmiveș and others against Romania, accessed on 22.11.2019.
} 


\section{FORMS OF SOCIAL REACTION AGAINST CRIMINALITY}

probation staff, this project representing a distinct measure included in the Justice Chapter from the 2018 - 2020 Government Program ${ }^{14}$.

Regarding the main activities of the probation services, we mention that in 2018, the probation counselors prepared 9.613 evaluation reports, 100.703 files on criminally sanctioned persons, 9.159 supervised or deprived of liberty persons benefited from specialized interventions with the purpose of community reintegration ${ }^{15}$.

For example, the European Probation Confederation which promotes the social inclusion of offenders through community sanctions and measures such as probation, community service, mediation and conciliation is committed to increase the profile of probation and to improve professionalism in this field, at national and European level ${ }^{16}$.

\section{MIXED MODELS OF SOCIAL REACTION ${ }^{17}$ - GUARANTY MEASURES}

This type of model comprise the prevention with repression when applying a criminal punishment, emphasizing the dual need to apply a punishment measure with the role of re-educating and preventing the relapsing of a deviant behavior and of canceling effects of a criminal offense ${ }^{18}$. The literature defines the guaranty measures found in the Criminal Code $^{19}$ as a mixed model, following their application society being protected against perpetrators and also the individual being protected by the occurrence of applying a penalty in what concerns him $^{20}$.

In the contemporary conception, guaranty measures are interpreted as penalties of criminal nature. The main difference between punishments and guaranty measures is that punishments can only be applied to offenders (who have committed an act that sums up the conditions of the crime translated in the penal code) while guaranty measures can be applied to those who have the quality of a perpetrator (be they minors or persons without discernment), respectively those who have committed simple unjustified acts provided by the criminal law ${ }^{21}$.

As regards the dismissal of the danger state, the applicability of the guaranty measures proves its efficiency by its immediate application, constituing a way by which the danger state is removed and replaced with a security state necessary for the lawful order $^{22}$. The purpose consists in that by taking a guaranty measure, it acts as a barrier to reiterating illicit behavior. Preventing a crime means, from the point of view of the specialists in criminal law, "to put an obstacle in the way of the reality from which the state of danger arises and to prevent it from leading or contributing to the commission of such acts" $^{23}$.

\section{MEANS OF SOCIAL CONTROL - ETIOLOGICAL PERSPECTIVES}

\footnotetext{
14 Available at www.just.ro/wp-content/uploads/2015/09/RAPORT-DE-ACTIVITATE-DNP-2018-depublicat2.pdf, Sistemul de Probaţiune - Raport de activitate 2018, accessed on 22.11.2019.

${ }^{15}$ Idem.

${ }^{16}$ Available at www.cep-probation.org/about-confederation-of-european-probation/, accessed on 22.11.2019.

${ }^{17}$ M. Sandu, op. cit., p. 39.

18 P. H. Robbinson, Crime, punishment, and prevention, p. 61, available at www.nationalaffairs.com/ public_interest/detail/crime-punishment-and-prevention, accessed on 22.11.2019.

${ }^{19}$ Article 107 paragraph (1) of the Penal Code.

${ }^{20}$ Article 5, paragraph 1, letter e) of the European Convention on Human Rights and article 6 of the Charter of Fundamental Rights of the European Union.

${ }^{21}$ V. Pașca, Drept Penal - Partea generală, Ed. Universul Juridic, Bucharest, 2014, p. 499.

${ }^{22}$ Idem, p. 500.

${ }^{23}$ V. Pașca, op. cit. p. 501, apud. V. Dongoroz and others, op. cit., p. 280.
} 


\section{Alina Zaharia}

The social control aims to establish a strong connection between the society and its members, a beneficial interaction for both parties. As an expected result of social control, the individual should exhibit strong adherence to the norms and values of the community and the group to which he belongs, thus taking on identity and personality in relation to society ${ }^{24}$.

Without assuming any form of social control, an individual can easily pass under the notion of anomos ${ }^{25}$ which is defined as a "social instability arising from the rupture between the individual and human values" ${ }^{\prime 26}$.

There are two forms of social control that are dissected from the point of the rules origin. Therefore, two modalities of social control exist, the formal and the informal one. Characterizing the informal nature of this concept, we expose the idea that the societies norms and values, as well as the adoption of a system of beliefs learned through the socialization process, represent a form of conformity and adaptation of the society's members. The initiators of this category are parents, caregivers, teachers, coaches ${ }^{27}$. "It represents the result of socialization within the existing social normativity and of social learning, that is, of internalizing the system of norms, behavioral patterns and attitudes typical for a society" ${ }^{28 .}$

Formal social control is defined by the institutional norms of legislative character, evoked by the institutions of a state, the organizations or corporations regulations etc. ${ }^{29}$.

By categorizing the notion of social control between formal and informal, we understand a different interpretation that each individual has. At the same time, these two notions are interdependent, the behavior of an individual being characterized through the prism of the set of values or original norms which are then propagated in the way of observing the institutionalized rules imposed by an organizational structure ${ }^{30}$.

The discrepancy between the intrapersonal characteristics of the individual and the imperative norms imposed on him by a certain institutional or organizational structure can lead to his non-compliance with this type of norms.

There is the opinion that the imposed institutional norms would be conceived at a generally valid level, thus the applicability and their keeping by the members of a society can be made difficult, given that the diversity of individuals is infinite, therefore the proper observance of such a norm can be relative and interpreted through the prism of each one's cognitive-behavioral constitution ${ }^{31}$.

Criminological aspects of social control are essential in the application, understanding and observance of certain norms. The branch of critical criminology refers to the lack of causal theories that explain the inevitable occurrence of criminality and the connection between social structure, social order, semantics of society and crime, and not least, the lack of theories and scientific explanations regarding the usefulness of norms in the criminal sphere, as a form of social control ${ }^{32}$.

\footnotetext{
24 Available at www.dreptmd..com/cursuri-universitare/sociologie-juridica/cursul-nr-10-controlul-social, accessed on 22.11.2019.

${ }^{25}$ a-nomos - without law (Social anomie theory - R. K. Merton), www.etymonline.com/word/anomyk, accessed on 22.11.2019.

${ }^{26}$ Available at www.merriam-webster.com/dictionary/anomie, accessed on 22.11.2019.

${ }^{27}$ I. Meszaros, The necesity of social Control, Monthly Review Press, New York, 2015, p. 35.

${ }^{28}$ C. Zamfir, L. Vlăsceanu, Dicţionar de sociologie, p.139.

${ }^{29}$ I. Vlăduţ, Introducere în sociologia juridică, Ed. Lumina Lex, Bucharest, 2003, p. 155.

${ }^{30}$ S. Karstedt, K. - D. Bussmann, Social Dynamics of Crime and Control - New Theories for a World in transition, Hart Publishing, 2000, p. 249.

${ }^{31}$ C. I. Loghin, op.cit, p. 66.

${ }^{32}$ S. Karstedt, K. - D. Bussmann, op. cit., p. 244.
} 


\section{FORMS OF SOCIAL REACTION AGAINST CRIMINALITY}

Regarding the extremely heterogeneous composition of the population and the high mobility among the inhabitants of certain parts of an area, these can be regarded as causes of the lack of social cohesion and, indirectly, of the comprising of the criminality characteristics.

Concerning that ethnic segregation and poverty concentration go hand in hand with an increase in violence, violent criminality can continue to increase by establishing illegal markets and organized crime, emphasizing ethnic conflicts and resentments and also through cultural or social adaptation of behavior in a threatening environment ${ }^{33}$.

\section{CONCLUSIONS}

Therefore, we conclude by exposing the idea that these three models, the preventive, the mixed and the social control one, sums up the perspectives and characteristics of a justice system that has parts of the restorative justice and are presented as beneficial methods on the way to carrying out the act of justice. By applying these models one can better take into account the needs and interests of an individual, given that understanding the original aspects of the occurrence of criminality, identifying the causes and making a criminological prognosis on the phenomenon of social deviance can prevent, but more importantly, can eliminate some generating factors of this current.

The lack of empathy related to the organizational and functional structure of a criminal mindset has certain causes, certain items that once identified can be transposed in the ways to combat and prevent crime, while also highlighting the etiological, preventive and explanatory functions and the role of criminology as a science, criminogenic factors treated by this science (economic, demographic, socio-cultural factors) and the relationship with other branches (criminal law, criminal procedural law, forensics, legal medicine, judicial psychology, legal sociology).

\section{BIBLIOGRAPHY}

Charter of Fundamental Rights of the European Union.

European Convention on Human Rights.

European Probation Rules, European Rules on Comunity Sanctions and Measures Recomandation no. R(92) 16 on European rules on Community sanctions and measures, rm.coe.int/rec-92-16-on-community-sanctions-and-measures/16808b60b6.

Framework Decision 2008/947 / JHA of the Council of 27 November 2008, www.eurlex.europa.eu/legal-content/RO/TXT/HTML/?uri=CELEX:32008F0947\&from=EN.

The Penal Code of Romania published in the Official Monitor no. 510/24.07.2009.

Law no. 252/2013 on the organization and functioning of the probation system, published in the Official Monitor no. 512/14.08.2013.

Loghin C., Conflicte - metode alternative de administrare și soluționare, Ed. Univ. Alexandru Ioan Cuza, Iasi, 2016.

Sandu M., Reacția socială împotriva criminalității, Ed. Pro Universitaria, 2017.

Pașca V., Drept Penal - Partea generală, Ed. Universul Juridic, Bucharest, 2014.

Vlăduţ I., Introducere în sociologia juridică, Ed. Lumina Lex, Bucharest, 2003.

Zamfir C., Vlăsceanu L., Dicţionar de sociologie.

Karstedt S., Bussmann K. - D., Social Dynamics of Crime and Control - New Theories for a World in transition, Hart Publishing, 2000.

\footnotetext{
${ }^{33}$ Idem, p. 243.
} 


\section{Alina Zaharia}

Meszaros I., The necesity of social Control, Monthly Review Press, New York, 2015.

Rezmiveș and others against Romania, www.ier.gov.ro/wp-content/uploads/cedo/Rezmives-sialtii-impotriva-Romaniei.pdf.

Robbinson P. H., Crime, punishment, and prevention, www.nationalaffairs.com/ public_interest/detail/crime-punishment-and-prevention.

ec.europa.eu/info/law/cross-border-cases/judicial-cooperation/types-judicial-

cooperation/detention-and-transfer-prisoners_en.

www.cdep.ro/interpel/2016/r3286B.pdf.

www.cep-probation.org/about-confederation-of-european-probation/.

www.dreptmd..com/cursuri-universitare/sociologie-juridica/cursul-nr-10-controlul-social.

www.ec.europa.eu/growth/tools-

databases/regprof/index.cfm?action=regprof\&id_regprof $=16890$.

www.etymonline.com/word/anomyk.

www.euprobationproject.eul.

www.just.ro/comunicat-de-presa-referitor-la-protestul-consilierilor-de-probatiunel.

www.just.ro/directia-nationala-de-probatiunel.

www.just.ro/wp-content/uploads/2015/09/RAPORT-DE-ACTIVITATE-DNP-2018-de-

publicat2.pdf, Sistemul de Probațiune - Raport de activitate 2018.

www.merriam-webster.com/dictionary/anomie. 